\title{
The Common Interest Doctrine and Disclosures during Negotiations for Substantial Transactions
}

\author{
Anne King $\dagger$
}

\section{INTRODUCTION}

During negotiations for corporate transactions, each party involved shares non-public information with the other party. Information shared during negotiations is instrumental in assessing the financial and legal risks of doing business. Sometimes, one of the parties discloses communications protected by the attorney-client privilegesuch as a patent opinion letter or a memorandum assessing a corporate client's litigation risks.

Disclosure of a privileged document during business negotiations appears to work an implied waiver of the attorney-client privilege, meaning that the shared documents could be compelled in future litigation. Document sharing does not inexorably work a waiver: the law of evidence recognizes that parties with a common interest may share privileged communications without waiving the privilege.' Nevertheless, the "common interest doctrine" arguably does not protect disclosures during business negotiations. In order to come within the common interest doctrine, parties must share a common interest that is "legal, not solely commercial," ${ }^{2}$ and parties must anticipate collaboration in pending or future litigation. ${ }^{3}$ Under this definition, one might argue, corporations engaged in negotiations do not share a common interest because each party seeks to maximize its commercial gain

$\dagger$ BA 2001, The University of Chicago; MAT 2003, Johns Hopkins University; JD candidate 2008, The University of Chicago.

1 See, for example, Restatement (Third) of the Law Governing Lawyers $\$ 76$ (2000) (recognizing the common interest doctrine, and stating that "[i]f two or more clients with a common interest in a litigated or nonlitigated matter ... agree to exchange information concerning the matter," and their communication of such information "otherwise qualifies as privileged," then the communication "is privileged as against third persons").

2 DuPlan Corp v Deering Milliken Inc, 397 F Supp 1146, 1172 (D SC 1974) ("A community of interest exists among different persons or separate corporations where they have an identical legal interest with respect to the subject matter of a communication between an attorney and a client concerning legal advice.").

3 Id. See also note 77 (noting that courts will apply common interest protection even when anticipated litigation is far in the future). 
through the transaction. ${ }^{4}$ And the choice to disclose a privileged document suggests that the corporation assigns greater value to the outcome of the transaction than it assigns to the privilege.

However, when two corporations are negotiating a substantial transaction ${ }^{5}$ - such as a merger, a substantial asset sale, or a subsidiary divestiture-there is a stronger case that a common interest exists between the parties. In particular, when parties to negotiations contemplate a change of control from one party to the other, their negotiations are likely to touch on how future litigation might affect both parties.

The timing of the disclosure is also relevant to the question of waiver. During the course of substantial transactions, potential buyers conduct rigorous due diligence review, ${ }^{6}$ scrutinizing the seller corporation's files, records, and financial statements to assess the transaction's risk.' Disclosures during due diligence arguably warrant different . treatment than disclosures made during the initial stages of negotiations. The parties to the contemplated transaction are less likely to have adverse interests at this late stage of negotiations. Also, the case for implied waiver is weaker because strong norms, based in legal rules, influence the practice of due diligence disclosure.

Most courts conclude that disclosures made during transaction negotiations work a waiver of the attorney-client privilege, and thus

4 See Oak Industries $v$ Zenith Industries, 1988 US Dist LEXIS 7985, *11 (ND IIl) ("[W]hatever the common interest shared by parties at the negotiating table, it is insufficient to warrant [common interest protection].").

5 This Comment will use the phrase "substantial transaction" to refer to major transactions that involve a change in control of a corporation or a substantial portion of a corporation, such as a merger or subsidiary divestiture, the sale of a division, or a transfer of substantial assets. As used in this Comment, a substantial transaction is one in which process duty of care is implicated. See Smith v Van Gorkom, 488 A2d 858, 872 (Del 1985) (establishing the requirement that directors inform themselves about the risks and benefits of major transactions before voting to approve or reject such a proposed transaction). See also text accompanying note 18 (discussing process duty of care). "Substantial transaction," as used here, does not refer, for example, to minor sales of assets or sales of goods or services.

6 For the purposes of this Comment, "due diligence" will refer to pretransaction review for the purpose of assessing the transaction's risks and synergies, not review in preparation for securities offerings. One commentator suggests that the process of "due diligence" as practiced in contemporary corporate transactions has roots in the due diligence defense to actions under the Securities Act of 1933 and the Securities Act of 1934. See David A. Katz, Due Diligence in Acquisition Transactions, in Conducting Due Diligence 2005 245, 249 (Practising Law Institute). Also, this Comment will focus primarily on buyer due diligence rather than seller due diligence, which is less extensive. "The seller usually conducts a far more limited investigation designed to assure itself that it has satisfied relevant regulatory obligations." Jeffrey C. Fort, Roger W. Patrick, and Maribeth Flowers, Due Diligence for Environmental Issues in Transactions, in Attorney's Guide to Environmental Liability in Transactions $\S 1, \S 1.1$ (Illinois Institute for Continuing Education 1991).

7 See Katz, Due Diligence in Acquisition Transactions at 250 (cited in note 6) ("[T]he term due diligence refers to ... the investigation that is part of nearly every ... corporate acquisition."). 
courts decline to allow common interest protection. ${ }^{8}$ But a few courts hold that disclosures during negotiations for a substantial transaction may be protected under the common interest doctrine.' Hence, with respect to substantial transactions, courts are split as to whether common interest protection applies to disclosures made during negotiations. Because the law is unsettled on this point, it is difficult for corporations engaged in a transaction to predict whether, in a future action, courts will find that they shared a common interest at the time of disclosure. This Comment argues that, to best accord with corporate law's preference for predictability in transaction planning but still avoid allowing excessive privilege, courts should apply common interest protection only when certain factors are present.

Part I offers an overview of substantial corporate transactions, including a description of due diligence review, the legal rules that influence disclosure of information during due diligence review, and the law governing succession of liabilities in substantial transactions. Part II outlines the law of the attorney-client privilege and the evolution of the common interest doctrine. Part III discusses how courts apply the common interest doctrine when corporations share privileged communications during the course of business transactions, and outlines courts' divergent positions regarding disclosures made during the course of substantial transactions. Part IV identifies a set of circumstances under which common interest protection is most justified because (1) objective indicators suggest a common interest existed between the two corporations at the time of disclosure, and (2) adverse interests did not overwhelm the corporations' common interest. This Comment argues that courts should recognize a presumption that substantial transaction disclosures are protected under the common in-

8 See, for example, Libbey Glass, Inc $v$ Oneida, Ltd, 197 FRD 342, 349 (ND Ohio 1999) (declining to allow protection on the grounds that "Oneida sought commercial gain, not legal advantage, through disclosure of its lawyer's advice"); Oak Industries, 1988 US Dist LEXIS 7985 at *11 (declining to allow protection on the grounds that expanding the privilege "would quickly swallow up the general rule that disclosure waives the attorney-client privilege"); SCM Corp v Xerox Corp, 70 FRD 508, 525 (D Conn 1976) (declining to allow protection of information disclosed during negotiations on the grounds that the party seeking protection failed to show that there was a "reasonable basis for assuming that the [shared information] ... sufficiently concerned the risk of [the negotiation partners'] shared exposure to liability").

9 See, for example, Tenneco Packaging Specialty \& Consumer Products, Inc v S.C. Johnson \& Son, Inc, 1999 US Dist LEXIS 15433, *7 (ND Ill 1999) (restating the common interest rule and holding that legal advice shared during due diligence falls within it); Rayman v American Charter Federal Savings \& Loan Association, 148 FRD 647, 653-55 (D Neb 1993) (holding that disclosure of documents to a negotiation partner regarding a pending lawsuit did not waive the attorney-client privilege), revd on other grounds, 75 F3d 349 (8th Cir 1996); Hewlett-Packard Co v Bausch \& Lomb, Inc, 115 FRD 308, 310 (ND Cal 1987) ("[I]t seems clear that defendant and [its negotiation partner, with whom it shared documents] anticipated litigation in which they would have a common interest. Moreover, their common interest would have been in identical issues of law and fact."). 
terest doctrine only where two factors are satisfied: (1) disclosure occurred during due diligence review, and (2) the transaction, if consummated, would lead to succession of liability.

\section{SUBSTANTIAL TRANSACTIONS}

When corporations contemplate a substantial transaction - that is, a large scale transaction that may result in transfer of liabilities from one corporation to another ${ }^{10}$ - the potential buyer and seller take great care in evaluating the transaction's risks, including the liabilities that will transfer. This Part offers an overview of due diligence review and concludes with a brief summary of the law governing succession of liabilities.

\section{A. Due Diligence Review}

During due diligence review a seller (or target) typically makes available relevant documents in a secured data room or via a secured due diligence website. ${ }^{11}$ Although a seller initially controls which documents it provides to a potential buyer, a sophisticated buyer will likely request access to additional documents. A buyer's request, like a request for document production during discovery, will be phrased in very general terms that capture a wide range of documents. ${ }^{12}$ Because a seller will likely give potential buyers access to confidential documents, the parties to a transaction normally enter into a confidentiality agreement."

Due diligence review, the "detailed investigations necessary to informed decisions about acquisition[s]" or mergers, ${ }^{14}$ is a critical phase

10 For a more detailed definition of "substantial transaction," see note 5.

11 See Committee on Negotiated Acquisitions, The M\&A Process: A Practical Guide for the Business Lawyer 179-81 (ABA 2005) (describing the advantages and disadvantages of virtual data rooms). A data room will be available in solicited transactions (especially auctions), but typically is not available in the takeover context. "In the context of an unsolicited transaction, the potential acquirer must be prepared to act on the basis of available public information." Katz, Due Diligence in Acquisition Transactions at 252 (cited in note 6).

12 One sample due diligence document request, for example, asks that the seller tender "[a]1l correspondence with, reports of or to, filings with, or other material information with respect to any other regulatory bodies which regulate a material portion of the Company's business." Id at 311. One can imagine that certain privileged documents, such as an opinion letter assessing the company's risk of violating a given regulation, would fall under that description.

13 Id at 252 ("[T]he potential acquiror will have signed some form of confidentiality agreement in exchange for confidential information regarding the target company."). "If the transaction does not proceed, confidentiality agreements usually require the return of the information and destruction of.any documents which contain the information." Id at 301.

14 In re Integrated Resources, Inc, 147 BR 650, 654 (SDNY 1992). One commentator summarized the "investigation's" goals as follows: "[I]t can limit professional liability, identify areas of weakness in the target company, identify possible synergies following the transaction, and 
of substantial transactions. ${ }^{\text {is }}$ The information collected during due diligence review affects the transaction's final price, influences the parties' negotiation of indemnification clauses, and may even lead to abandonment of the transaction. For example, upon finding a significant risk, a potential buyer may lower its bid. Also, in a contract to purchase assets, information gleaned during due diligence may lead the buyer to propose tailored indemnification clauses to insulate itself from risk. ${ }^{16}$ Although proposed contracts typically include boilerplate indemnification clauses, due diligence better equips the buyer to negotiate clauses accurately reflecting the transaction's liability risks. ${ }^{17}$ Finally, if risks cannot be off-set by a lower price or indemnification, the buyer may abandon the transaction.

Another function of due diligence is to shield the corporation's management from liability. Corporate directors view due diligence as a means to avoid process duty of care liability, which requires that directors inform themselves about the risks and benefits associated with corporate decisions. ${ }^{18}$ Directors considering a substantial transaction use the due diligence process to inform themselves about potential risks; hence, a due diligence investigation offers protection from process duty of care liability.

In addition to its liability-protection and risk-assessment functions, due diligence has a third function: it eases a buyer's posttransaction transition. During due diligence, a buyer acquires knowledge about the operation and management of the corporation, division, or assets it seeks to acquire. This acquired knowledge-and resulting reduction in transition costs-adds to the value of due diligence review for the buyer.

generally provide relevant information for the management of the new entity." William M. Brown, Grandfathering Can Seriously Damage Your Wealth: Due Diligence in Mergers and Acquisitions of Medical Device Companies, 36 Gonz L Rev 315, 340 (2001).

15 Due diligence review is particularly important in transactions involving closely held corporations. Information about publicly held corporations is widely available, but an entity contemplating a transaction with a closely held corporation likely has access to very little information on which to base an assessment of the transaction's financial risk.

16 See Katz, Due Diligence in Acquisition Transactions at 251 (cited in note 6) (noting that information acquired during diligence will affect the price of the transaction, "including any post-transaction indemnification obligations").

17 See Tarek N. Fahmi, IP Due Diligence: Methodologies and Practices, in Handling Intellectual Property in Business Transactions 2004 841, 849-50 (Practicing Law Institute) ("[D]ue diligence can be used as a foundation for allocating risk among the parties to a transaction through appropriate contractual provisions. .. Too often, companies will attempt to use boilerplate representations and warranties in an agreement as a substitute for proper due diligence.").

18 See, for example, Smith v Van Gorkom, 488 A2d 858, 872 (Del 1985) (establishing that the business judgment rule applies only when directors have made an informed decision). 
Due diligence is costly for both buyers and sellers. ${ }^{19}$ Both parties incur costs for the lawyers and accountants who oversee the due diligence process, and a seller incurs costs in gathering documents. ${ }^{20}$ As outlined above, the benefits of due diligence review accrue primarily to buyers. But if a planned transaction is not consummated, a would-be buyer gains no benefit from its outlay. ${ }^{21}$ Thus, given the significant costs associated with due diligence review, parties' willingness to enter this phase of a transaction is a predictor of the transaction's consummation.

\section{B. Succession of Liabilities in Substantial Transactions}

Transfer of liabilities between the parties to a substantial transaction depends on whether the transaction results in succession - that is, automatic assumption of liabilities. If a buyer does not succeed to the seller's liabilities, parties must engage in negotiations to determine what liabilities will transfer. The transaction's structure dictates whether a buyer corporation will automatically succeed to the seller corporation's liabilities. In a merger, the surviving corporation suc-

19 See Katz, Due Diligence in Acquisition Transactions at 258 (cited in note 6) ("The due diligence process may be very expensive due, in part, to the mass of documentation to be obtained and reviewed, and the time consuming work to prepare detailed written reports."). It is difficult to state precisely the cost of due diligence, although the expense involved might be roughly estimated by looking to "break-up fees." Break-up fees, which are "paid to a potential acquiror of a business, or certain assets, by the seller, in the event that the transaction contemplated fails to be consummated and certain criteria in the purchase agreement are met," In re Integrated Resources, Inc, 135 BR 746, 750 (Bankr SDNY 1992), serve as a type of liquidated damages provision. "Break-up fees may take the form of paying the [acquiror's] out-of-pocket expenses incurred in arranging the deal, including due diligence expenses, or break-up fees may be wholly independent of the transaction costs[, possibly encompassing] a bidder's lost opportunity costs." Id. Bankruptcy decisions offer good data on the scope of break-up fees, because the court must approve such fees. See, for example, Integrated Resources, 135 BR at 753 (approving a break-up fee of $\$ 6$ million attached to an offer to loan $\$ 565$ million); In re 995 Fifth Avenue Associates, LP, 96 BR 24, 28 (Bankr SDNY 1989) (approving a $\$ 500,000$ break-up fee attached to a $\$ 73$ million bid). Of course, these figures offer only a rough idea because break-up fees may compensate for other losses, see Integrated Resources, $135 \mathrm{BR}$ at 750, but they offer a sense of the expense involved in due diligence review.

20 See Katz, Due Diligence in Acquisition Transactions at 261 (cited in note 6) (noting that "it will normally be necessary to employ a team of lawyers (and perhaps investment bankers and other specialists)").

21 See id at 300 ("[Due diligence] becomes a very expensive process for the acquiror if it chooses to terminate the process or to bear extra costs if items which should have been taken into account during the due diligence investigation arise later in the process."). See also Committee on Negotiated Acquisitions, The $M \& A$ Process at 190 (cited in note 11) ("There are risks to the buyer in being involved in an unsuccessful purchase. While the consequences of completing a bad deal almost always outweigh the consequences of not doing a particular deal, the latter consequences are not insignificant."). 
ceeds to the liabilities and assets of the target corporation, ${ }^{22}$ including the target corporation's privileges. ${ }^{23}$ In an asset sale, however, the buyer does not automatically succeed to the seller's liabilities. ${ }^{24}$ The rationale for the asset sale default rule "is the interest in a fluid market in corporate assets, which is impeded if purchasers acquire along with the assets legal liabilities of unknown, sometimes unknowable, dimensions." 25

There are several exceptions to the default rule for asset sales. ${ }^{26}$ Successor liability - that is, automatic liability for asset purchasers-applies under certain circumstances to ensure that a dissolved corporation's creditors have the opportunity to pursue a remedy. The basic requirements for successor liability are "continuity between the predecessor's and successor's businesses and the latter's notice of the former's acts."

Certain exceptions to the asset sale default rule - the mere continuation, ${ }^{28}$ de facto merger, ${ }^{29}$ and fraudulent transfer exceptions - are primarily intended to prevent fraud to creditors. ${ }^{30}$ For example, with-

22 See Stephen M. Bainbridge, Corporation Law and Economics $\S 12.3(\mathrm{~A}$ ) at 623 (Foundation 2002) (noting that "the survivor [corporation] will have succeeded by operation of law to all of the assets, liabilities, rights, and obligations of the two constituent corporations").

23 Similarly, in a triangular merger, the newly created subsidiary succeeds to the liabilities of the target corporation. See id $\$ 12.3(\mathrm{C})$ at 630 ("After a triangular merger, the target remains in existence as a wholly owned subsidiary of the true acquirer... [T] ration's exposure to successor liability is limited to its investment in the acquired subsidiary."). To effect a triangular merger, the acquiring company creates a subsidiary, which then merges with the target. Id. A somewhat analogous result follows from a stock acquisition in which the target becomes a subsidiary of the buyer. The target's pre-sale liabilities are confined to the subsidiary; the buyer faces liability only through piercing of the corporate veil. See Brown, 36 Gonz L Rev at 325-26 (cited in note 14) (discussing the state of a target's pre-sale liabilities after a stock sale).

24 See Ruiz v Blentech Corp, 89 F3d 320, 324 (7th Cir 1996) (describing the default rule in asset sales as "a basic rule about corporate successor liability").

25 EEOC $v$ Vucitech, 842 F2d 936, 944 (7th Cir 1988) (describing the common law rule, "now eroding, that in a sale of assets ... a purchaser took free of any liabilities not expressly assumed, including tort liabilities") (citations omitted).

26 Successor liability exceptions vary by state. See Ruiz, 89 F3d at 324 (discussing state-law exceptions to the general rule against successor liabilities in asset purchases).

27 Vucitech, 842 F2d at 944.

28 A "mere continuation" is "an entity that differ[s] only formally from its successor." Michael D. Green, Successor Liability: The Superiority of Statutory Reform to Protect Products Liability Claimants, 72 Cornell L Rev 17, 23 (1986) (“A successor whose ownership, management, and corporate operations are the same as its predecessor is not a separate economic entity simply because of formalistic changes. Thus, the economic unit that incurred the liability remains responsible for it.").

29 A "de facto merger" is a judicial finding of merger although the deal was structured as an asset sale: the "court re-characterizes an asset transfer as though it were a statutory merger of the transferor with the transferee because the transferee is, in substance, indistinguishable from the transferor." Marie T. Reilly, Making Sense of Successor Liability, 31 Hofstra L Rev 745, 747 (2003).

30 See id at 750-51 (arguing that fraud concerns underlie the de facto merger and mere continuation rationale for successor liability, in addition to the fraudulent transfer rationale). 
out the guarantee of successor liability in cases of mere continuations, an entity could transfer substantially all of its assets to another entity and then dissolve, leaving no entity liable for residual debts. However, policy concerns also animate successor liability exceptions. For example, one rationale for the product line successor liability rule-which applies when the purchaser acquires an entire product line-is the idea that manufacturers can manage product risk more efficiently than consumers. ${ }^{31}$

Federal courts also impose successor liability on a purchaser of assets when that purchaser has notice that the seller corporation could have been liable under certain federal statutes. For example, a successor may be liable for Title VII employment claims ${ }^{32}$ or environmental claims $^{33}$ based on its predecessor's practices. For federal successor liability, notice of a possible claim is not sufficient; there must be "substantial continuity between predecessor and successor.,"

Finally, succession of liabilities is relevant to whether the attorney-client privilege is transferred in a substantial transaction. In a merger, the target corporation's attorney-client privilege always transfers to the surviving corporation. ${ }^{35}$ Also, privilege passes to the buyer in the sale of a subsidiary. ${ }^{36}$ In a simple asset sale, the privilege does not necessarily transfer; the seller may still hold control. ${ }^{37}$ However, under some circumstances the privilege does transfer through an asset sale; the existence of successor liability may allow the buyer to assert the attorney-client privilege as to the assets it purchased. ${ }^{38}$

31 See Green, 72 Cornell L Rev at 28 (cited in note 28) (naming justifications offered for liberal successor liability, including the ideas that "from the perspective of an injured claimant, the details of corporate acquisition are irrelevant ... [and] accident losses can best be minimized by imposing liability on the successor").

32 See Rojas v TK Communications, Inc, 87 F3d 745, 749-50 (5th Cir 1996) (discussing successor liability for employment claims).

33 See United States v General Battery Corp, 423 F3d 294, 298 (3d Cir 2005) (discussing successor liability for CERCLA claims).

34 Vucitech, 842 F2d at 945 (quotation marks omitted).

35 See Commodity Futures Trading Commission v Weintraub, 471 US 343, 349 ("[W]hen control of a corporation passes to new management, the authority to assert and waive the corporation's attorney-client privilege passes as well."').

36 See McCaugherty v Siffermann, 132 FRD 234, 245 (ND Cal 1990) ("Since the attorneyclient privilege over a corporation belongs to the inanimate entity and not to individual directors or officers, control over privilege should pass with control of the corporation.").

37 Soverain Software LLC v Gap, Inc, 340 F Supp 2d 760, 763 (ED Tex 2004) (A "mere transfer of some assets ... from one corporation to the other does not transfer the attorneyclient privilege."). See also Ramada Franchise System, Inc v Hotel of Gainesville Associates, $988 \mathrm{~F}$ Supp 1460, 1464 (ND Ga 1997) ("The mere sale or transfer of a portion of a corporation's assets does not necessarily transfer the corporation's attorney-client privilege.").

38 See Soverain Software, 340 F Supp $2 \mathrm{~d}$ at 763 (concluding that the buyer of an entire product line could assert the attorney-client privilege as a successor). 


\section{THE ATTORNEY-CLIENT PRIVILEGE AND THE COMMON INTEREST DOCTRINE}

The common interest doctrine permits coordination of efforts by separate parties' attorneys, including disclosure of communications protected under the attorney-client privilege. This Part provides a background on privilege law, particularly as practiced in the federal courts. Part II.D describes the evolution of the common interest as a further protection of privileged communications.

\section{A. Privilege Generally}

Evidentiary privileges are not lightly created or broadly construed. ${ }^{39}$ Overly broad privilege prevents the admission of relevant evidence, and inhibits the truth-finding purpose of the courts. ${ }^{40} \mathrm{Ex}-$ panding existing privileges - or recognizing novel privileges-reduces litigants' access to relevant information. Still, expansions or novel privileges are justified when a "public good transcend[s] the normally predominant principle of utilizing all rational means for ascertaining truth."

The Federal Rules of Evidence leave privilege determinations in federal question cases to federal common law. ${ }^{42}$ Hence, federal courts have the authority to craft privilege law - within limits. The Supreme Court has imposed two principal guidelines for lower courts to follow. First, the Court has endorsed the utilitarian approach ${ }^{43}$ - which maintains that privilege is meant to encourage certain valuable communications that would not otherwise occur-to defining privilege. ${ }^{4}$ Lower

39 See United States $v$ Nixon, 418 US 683, 710 (1974) ("[E]xceptions to the demand for every man's evidence are not lightly created nor expansively construed, for they are in derogation of the search for truth.").

40 See United States $v$ Bryan, 339 US 323, 331 (1950) ("[T] he public ... has a right to every man's evidence.").

41 Trammel v United States, 445 US 40, 50 (1980), citing Elkins v United States, 364 US 206, 234 (1960) (Frankfurt dissenting).

42 See FRE 501 ("Except as otherwise required ... the privilege of a witness, person, government, State, or political subdivision thereof shall be governed by the principles of the common law as they may be interpreted by the courts of the United States.").

43 See Note, Developments in the Law: Privileged Communications, 98 Harv L Rev 1450, 1472 (1985). Under Dean Wigmore's widely accepted utilitarian test, privilege is recognized only when communications between parties were confidential when made; society benefits from protecting the parties' relationship; confidentiality is essential to the parties' relationship; and disclosure is more harmful than privilege protection. See id. Harm is assessed in terms of systemic harm, not harm to the individual parties. See id at 1473.

44 See Upjohn Co v United States, 449 US 383, 389 (1981) (applying the utilitarian test for privilege inquiry and noting that " $\mathrm{t}] \mathrm{his}$ rationale for the privilege has long been recognized by the Court"); Trammel, 445 US at 51 (noting that a privilege is only justified if it "promotes sufficiently important interests to outweigh the need for probative evidence"). 
courts are therefore bound to apply a utilitarian test. Second, lower courts are further limited by the Court's warning that privileges "are not lightly created nor expansively construed."

\section{B. The Attorney-Client Privilege}

The attorney-client privilege protects communications between a client and his attorney from compelled disclosure during the judicial process. ${ }^{46}$ The utilitarian rationale explains the privilege as encouraging communications that clients would fear making without protection. ${ }^{47}$ The privilege protects only communications-not underlying facts $^{48}$ - and attaches only to communications made for the purpose of securing legal assistance."

Privileges generally have a policy justification that is extrinsic to litigation. ${ }^{50}$ Under the utilitarian rationale for the attorney-client privilege, the privilege is designed to protect the relationship between the parties, as is the case with other privileges such as the psychotherapistpatient $^{\text {st }}$ or spousal privilege. ${ }^{52}$ But the attorney-client privilege is less easily pigeonholed within this conception; it also has a purpose intrinsic to litigation. In particular, the attorney-client privilege protects clients' efforts to obtain legal advice, and consequently improves the quality of litigation.

Corporations, like individuals, may invoke the attorney-client privilege. The utilitarian rationale is also cited as support for the corporate privilege. The recognition of the corporate privilege indicates a judgment that protecting communications between corporate representatives and attorneys is more valuable than exposing such commu-

45 Nixon, 418 US at 710.

46 See Upjohn, 449 US at 389 ("The privilege recognizes that sound legal advice or advocacy serves public ends and that such advice or advocacy depends upon the lawyer's being fully informed by the client.").

47 See, for example, Fisher v United States, 425 US 391, 403 (1976) ("[The attorney-client privilege] protects only those disclosures-necessary to obtain informed legal advice-which might not have been made absent the privilege.").

48 See Upjohn, 449 US at 395-96.

49 See Fisher, 425 US at 403.

50 See Christopher B. Mueller and Laird C. Kirkpatrick, Evidence under the Rules: Text, Cases, and Problems 1 (Aspen 5th ed 2004) (noting that two justifications for recognizing rules of evidence are to further substantive policies both extrinsic and intrinsic to the matter in litigation).

51 See Jaffee v Redmond, 518 US 1, 11-12 (1996) ("The psychotherapist privilege serves the public interest by facilitating the provision of appropriate treatment for individuals suffering the effects of a mental or emotional problem.").

52 See Trammel, 445 US at 53 (observing that the purpose of marital privilege is to "further[] the important public interest in marital harmony").

53 See Upjohn, 449 US at 394 (recognizing the corporate attorney-client privilege for a corporation). 
nications. In Upjohn Co v United States, ${ }^{\text {s4 }}$ the Court gave an additional rationale for recognizing the attorney-client privilege in the corporate setting: receiving frank advice from attorneys allows corporate clients to conform their behavior to the law. ${ }^{\text {s5 }}$ The Upjohn Court suggested that corporations, in contrast to the average individual, require the protection of the attorney-client privilege in planning their everyday affairs, not just in responding to legal challenges.

\section{Waiver of Privilege}

Privilege may be waived expressly, or it may be impliedly waived based on a privilege holder's actions. The doctrine of implied waiver is strict: any disclosure of privileged communications to an outside party normally works a waiver. ${ }^{57}$ There can be a great deal at stake in cases of implied waiver, because waiver as to one communication on a certain question works a waiver on all communications that address this question. ${ }^{58}$ Moreover, discussion of the general subject matter of a privileged communication may, but does not always, work an implied waiver."

There are few exceptions to the implied waiver doctrine. Only a minority of courts recognize selective waiver, which preserves the privilege except as to the entity to which communications -were disclosed. ${ }^{60}$ The rationale courts cite in rejecting selective waiver doctrine

54449 US 383 (1981).

55 Id at 392 ("In light of the vast and complicated array of regulatory legislation confronting the modern corporation, corporations, unlike most individuals, constantly go to lawyers to find out how to obey the law.") (quotation marks omitted). Compare John E. Sexton, $A$ PostUpjohn Consideration of the Corporate Attorney-Client Privilege, 57 NYU L Rev 443, 464 (1982) (noting that critics of the corporate attorney-client privilege "have argued that because of the exigencies of the regulatory state and because of their general business needs, corporations would communicate with attorneys even if the privilege were not available").

56 Upjohn, 449 US at 392 (observing that, in addition to reasons related to the degree of regulation, corporations more frequently consult lawyers because "compliance with the law in this area is hardly an instinctive matter").

57 See Note, 98 Harv L Rev at 1630 (cited in note 43) (noting that although courts have carved out exceptions to the doctrine in practice, they continue to state it in "absolute form").

58 See Smith v Alyeska Pipeline Service Co, 538 F Supp 977, 980-82 (D Del 1982).

59 See American Optical Corp v Medtronic, Inc, 56 FRD 426, 431 (D Mass 1972) (concluding that lawyer's disclosure of certain opinions during licensing negotiations did not waive privilege for communications).

60 Compare Diversified Industries v Meredith, 572 F2d 596, 611 (8th Cir 1977) (allowing selective waiver when documents were disclosed to a government agency), with Westinghouse Electric Corp v Republic of the Philippines, 951 F2d 1414, 1424 (3d Cir 1991) (declining to recognize selective waiver where a party disclosed documents to the Department of Justice pursuant to a subpoena). The Westinghouse court likened the acceptance of selective waiver to "creation of a new privilege allowing parties to disclose communications to government agencies" Id at 1425. The overwhelming majority of federal courts adopt the Westinghouse position on selective waiver. See In re Qwest Communications International Inc, 450 F3d 1179, 1201 (10th Cir 2006); In re Columbia/HCA Healthcare Corp Billing Practices Litigation, 293 F3d 289, 291 (6th Cir 2002); United States 
is that it conflicts with the privilege's utilitarian rationale: "If clients themselves divulge [privileged] information to third parties, chances are that they would also have divulged it to their attorneys, even without the protection of the privilege." ${ }^{61}$ However, although inadvertent disclosure of privileged communications historically worked an implied waiver, ${ }^{62}$ some courts have engaged in a balancing inquiry in cases of accidental dissemination. ${ }^{63}$ And recent amendments to the Federal Rules of Civil Procedure provide a procedure that may be invoked when a party unintentionally produces privileged documents: upon the producing party's notification, the party who received the documents "may not use or disclose [them] until the [privilege] claim is resolved."

Implied waiver doctrine is grounded in the concern that privilege operates to obscure relevant evidence. Some courts read disclosure as evidence of intent to waive the privilege. ${ }^{65}$ Other courts justify implied waiver on the reasoning that waiver should occur whenever the privilege holder's actions are inconsistent with the purpose of the privi-

v Massachusetts Institute of Technology, 129 F3d 681, 686 (1st Cir 1997); In re Martin Marietta Corp, 856 F2d 619, 623 (4th Cir 1988); The Permian Corp v United States, 665 F2d 1214, 1222 (DC Cir 1981). Compare In re LTV Securities Litigation, 89 FRD 595,621-22 (ND Tex 1981) (allowing assertion of privilege as to documents disclosed to the SEC during an investigation). In 2006, the Evidence Rules Advisory committee proposed amendments to the Federal Rules of Evidence to address the split on selective waiver. Proposed Federal Rule of Evidence 502(c) provides for selective waiver when communications are disclosed to state or local government agencies. See Proposed FRE 502(c), available online at http://www.uscourts.gov/rules/Excerpt_EV_Report_Pub.pdf (visited Sept 12, 2007). See generally Kenneth S. Broun and Daniel J. Capra, Getting Control of Waiver of Privilege in the Federal Courts: A Proposal for a Federal Rule of Evidence 502, 58 SC L Rev 211 (2006) (describing the drafting process for Proposed FRE 502).

61 Westinghouse, 951 F2d at 1424, quoting Comment, Stuffing the Rabbit Back into the Hat: Limited Waiver of the Attorney-Client Privilege in an Administrative Agency Investigation, $130 \mathrm{U}$ Pa L Rev 1198, 1207 (1982).

62 See Bank Brussels Lambert v Credit Lyonnais (Suisse) SA, 160 FRD 437, 443 (SDNY 1995) (discussing the different approaches courts take to the issue of inadvertent disclosure).

63 See, for example, id (observing that "an attorney who takes reasonable precautions in discovery may avoid waiver even though he inadvertently discloses a privileged document," and naming factors relevant to the reasonableness inquiry, including "reasonableness of the precautions taken to prevent inadvertent disclosure," "the extent of the disclosure," and "overriding issues of fairness").

64 FRCP 26(b)(5)(B). The Advisory Committee observes that the rise in electronic discovery inspired the amendment to Rule 26(b). "When the review is of electronically stored information, the risk of waiver, and the time and effort required to avoid it, can increase substantially because of the volume of electronically stored information and the difficulty in ensuring that all information to be produced has in fact been reviewed." FRCP 26, Advisory Committee Notes to the 2006 Amendments.

65 See Richard L. Marcus, The Perils of Privilege: Waiver and the Litigator, 84 Mich L Rev 1605,1618 (1986) ("Although truly intentional waiver is rare in privilege cases, courts often talk of attempting to discern the privilege-holder's intention."), citing Suburban Sew 'N Sweep, Inc v Swiss-Bernina, Inc, 91 FRD 254, 260 (ND Ill 1981) (stating that the "relevant consideration" in assessing implied waiver "is the intent ... to maintain the confidentiality of the documents as manifested in the precautions they took"). 
lege. ${ }^{6}$ Still other courts-and many commentators-troubled by the implied waiver doctrine's categorical nature, offer a fairness justification for implied waiver. ${ }^{67}$ The fairness approach finds implied waiver only when communications are incompletely disclosed and fairness requires that the entire communication be disclosed to provide a complete context. ${ }^{68}$

\section{The Common Interest Doctrine}

A client has a privilege to refuse to disclose and to prevent any other person from disclosing confidential communications made for the purpose of facilitating the rendition of professional legal services to the client ... by him or his lawyer to a lawyer representing another in a matter of common interest. ${ }^{69}$

When two parties share a common legal interest, communications between them may be protected by the attorney-client privilege. Also, these parties or their attorneys may share existing privilege-protected communications without waiving privilege; work-product protected documents may also be disclosed without working a waiver. ${ }^{70}$ Courts

66 See, for example, United States $v$ AT\& T, 642 F2d 1285, 1299 (DC Cir 1980) ("Any voluntary disclosure by the holder of [the attorney-client] privilege is inconsistent with the confidential relationship and thus waives the privilege."). See also Marcus, 84 Mich L Rev at 1607 (cited in note 65) (describing the "purpose" justification for implied waiver doctrine).

67 See, for example, Remington Arms Co v Liberty Mutual Insurance Co, 142 FRD 408, 413 (D Del 1992) (discussing the concern that parties may selectively disclose privileged information to "garble the truth" and noting that, in this case, "fairness demands that the opposing party be allowed to examine the whole picture"); Golden Valley Microwave Foods, Inc v Weaver Popcorn Co, 132 FRD 204, 207 (ND Ind 1990) (concluding that an inadvertent disclosure did not constitute waiver given that the privilege holder was not intentionally engaging in truth garbling). See also Marcus, 84 Mich L Rev at 1607 (cited in note 65) (describing the "fairness" justification for implied waiver doctrine).

68 See Marcus, 84 Mich L Rev at 1608 (cited in note 65) ("[T]here is no reason for treating disclosure to opponents or others as a waiver unless there is legitimate concern about truth garbling or the material has become so notorious that decision without that material risks making a mockery of justice."). Courts recognizing the common interest doctrine often approve-either explicitly or implicitly-a fairness approach to implied waiver. For an explicit approval of Marcus's fairness approach, see Hewlett-Packard Co v Bausch \& Lomb, Inc, 115 FRD 308, 310-11 (ND Cal 1987) ("[I]n cases such as this, where the disclosure was in fact voluntary but not intended to create a waiver, the court agrees with Professor Marcus that one should look at the 'explicit or implicit undertaking by the recipient of the information to hold it in confidence."), quoting Marcus, 84 Mich L Rev at 1641 (cited in note 65). Hewlett-Packard is discussed in greater detail in Part III.B.2.

69 Proposed FRE 503(b), reprinted in Eutectic Corp v Metco, Inc, 61 FRD 35, 38 (EDNY 1973). Courts use a variety of terms to refer to this principle; this Comment uses the term "common interest doctrine" for the sake of consistency. A few sources cited in this Comment use the term "joint-defense doctrine." The original language used in the source has, in most cases, been retained when quoting from that source.

70 See, for example, United States $v$ Gulf Oil Corp, 760 F2d 292, 296 (Temp Emer Ct App 1985) (" $[\mathrm{I}] \mathrm{n}$ determining whether a disclosure is fatally inconsistent with maintaining [work product protection] the existence of 'common interests between [the parties] should be consid- 
variously classify the common interest doctrine as an extension of the attorney-client privilege ${ }^{n}$ or as an exception to the waiver doctrine. The common interest doctrine is widely accepted in the federal courts, and by state courts and legislatures.

The common interest doctrine, as applied today, evolved from the narrower principle that separate attorneys for criminal co-defendants may share trial strategies without waiving privilege. ${ }^{74}$ Over time, courts gradually extended this protection even where information sharing occurred before criminal charges were entered. ${ }^{75}$ Today, courts recognize the common interest doctrine when invoked by defendant or plaintiff, by corporation or individual, and in both civil and criminal matters. ${ }^{76}$ The common interest doctrine may also apply before litigation occurs, as long as the parties anticipate being possible targets of litigation in the area of their common interest. ${ }^{7}$ If the parties sharing a

ered."). In contrast to disclosure of privileged documents, disclosure of work-product protected communications does not automatically work a waiver. Id. This Comment will focus on the attorney-client privilege rather than work product protection. Because disclosure of work-product protected communications does not automatically work a waiver, the application of common interest protection for transaction-related disclosures is less controversial.

71 See, for example, Waller v Financial Corp of America, 828 F2d 579, 583 n 7 (9th Cir 1987).

72 See, for example, DuPlan Corp v Deering Milliken, Inc, 397 F Supp 1146, 1175 (D SC 1974).

73 Since its relatively recent emergence, the common interest doctrine has enjoyed wide acceptance among the states. See, for example, Ala R Evid 502(b) (incorporating Proposed FRE 503(b)'s formulation of the common interest doctrine); Ariz R Evid 501 (following FRE 501 in leaving to courts the task of developing privilege rules through the common law); Oxy Resources California $L L C$ v Superior Court, 115 Cal App 4th 874, 9 Cal Rptr 3d 621, 634-35 (2004) (noting that the California Evidence Code does not explicitly provide for a common interest or joint defense privilege, but recognizing a common interest doctrine as consistent with the Code's waiver provision). There is relatively little state court case law addressing the application of the common interest privilege to disclosures during negotiations; given the degree to which federal evidence law influences state evidence law, this Comment will focus primarily on federal decisions.

74 See James M. Fischer, The Attorney-Client Privilege Meets the Common Interest Arrangement: Protecting Confidences While Exchanging Information for Mutual Gain, 16 Rev Litig 631, 633 (1997) (noting that the common interest privilege originated in the criminal context). This principle was originally known as the joint-defense privilege, but as the doctrine expanded beyond the criminal sphere, the term common interest doctrine came into use.

75 See, for example, Hunydee v United States, 355 F2d 183, 185 (9th Cir 1965) (protecting communications made in a joint attorney-client conference to discuss the government's case against two individuals who faced indictment as co-defendants); Continental Oil Co v United States, 330 F2d 347,350 (9th Cir 1964) (protecting communications between attorneys for separate clients when the purpose of information sharing was to prepare their clients to testify before the same grand jury).

76 See United States $v$ Under Seal, 902 F2d 244, 249 (4th Cir 1990) (collecting cases that recognize the broad application of the common interest doctrine).

77 See, for example, Schachar $v$ American Academy of Opthalmology, Inc, 106 FRD 187, 191 (ND Ill 1985) ("Although originally limited to cases of actual co-defendants, courts have applied the joint defense privilege to cases of 'potential' litigation as well."). See also Nicole Garsombke, Note, A Tragedy of the Common: The Common Interest Rule, Its Common Misuses, and an Uncommon Solution, $40 \mathrm{Ga} \mathrm{L} \operatorname{Rev} 615,625$ (2006) (suggesting that courts provide insufficient justification for the expansion of the joint-defense doctrine); Gregory J. Kopta, Comment, Applying the Attorney-Client and Work Product Privileges to Allied Party Exchange of Informa- 
common interest are subsequently engaged in litigation against one another, common interest doctrine protection no longer applies."

The common interest doctrine shares characteristics of the work product doctrine. One justification for recognizing the common interest doctrine is that it conserves litigation resources and promotes fairness. ${ }^{79}$ Work product protection is similarly justified by the policy goal of permitting litigants to develop their best possible case. ${ }^{80}$ Furthermore, both the common interest doctrine and work product protection require anticipation of litigation, are judicially crafted, and have emerged relatively recently.

Common interest protection may be applied if three requirements are fulfilled: “(1) the communication was made by separate parties in the course of a matter of common interest, (2) the communication was designed to further that effort, and (3) the privilege has not been waived." third prong, requiring that parties with a common interest take steps to preserve the confidentiality of their communications. ${ }^{83}$ With respect to a disclosure made in the course of a transaction, the primary issues in applying the common interest doctrine are whether a disclosure was made "in the course of a matter of common interest" and whether "the communication was designed to further that effort."

tion in California, 36 UCLA L Rev 151, 155-58 (1988) (discussing the evolution of the contemporary common interest doctrine).

78 See Garner $v$ Wolfinbarger, 430 F2d 1093, 1103 (5th Cir 1970) (stating that "neither party [with a common interest] may exercise the privilege in a subsequent controversy with the other"); In re Sunrise Securities Litigation, 130 FRD 560, 573 (ED Pa 1989) ("The joint defense privilege is waived 'where one of the joint defendants becomes an adverse party in a litigation."').

79 See Deborah Stavile Bartel, Reconceptualizing the Joint Defense Doctrine, 65 Fordham L Rev 871, 914 (1996).

80 See Hickman v Taylor, 329 US 495, 511-12 (1947). See also Bartel, 65 Fordham L Rev at 915-18 (cited in note 79) (comparing work product protection and the common interest doctrine).

81 See Hickman, 329 US at 511 (articulating the work product protection doctrine in a 1947 opinion); Continental Oil, 330 F3d at 350 (articulating the joint-defense privilege in a 1964 opinion).

82 In re Mortgage \& Realty Trust, 212 BR 649, 653 (Bankr CD Cal 1997), citing In re Bevill, Bresler \& Schulman Asset Management Corp, 805 F2d 120, 126 (3d Cir 1986) (articulating a three-prong test for the joint defense doctrine) (additional citation omitted). Prong one might be expanded by a requirement that counsel for all parties be present at the time of the communication. See Libbey Glass, Inc v Oneida Ltd, 197 FRD 342, 348 (ND Ohio 1999).

83 See, for example, Libbey Glass, 197 FRD at 348.

84 A possible argument against recognizing common interest protection for transaction disclosures is that information sharing during transaction negotiations occurs too far in advance of potential litigation to justify common interest protection. However, courts do not rely on this argument, focusing instead on the nature of the claimed common interest. See, for example, $S C M$ Corp $v$ Xerox Corp, 70 FRD 508, 514 (D Conn 1976) (noting that regardless of whether the privileged communication referenced pending litigation or the possibility of litigation, "the privilege should not be denied when the common interest is clear"). Indeed, in contrast to individuals, corporations frequently make use of legal advice when planning future actions, not only when faced with immediate litigation. If the common interest doctrine is to be applied to corporations 


\section{THE COMMON INTEREST DOCTRINE AND SUBSTANTIAL TRANSACTIONS}

\section{A. The Common Interest Doctrine and Commercial Interests}

The most widely cited test for what constitutes a common interest is the formulation articulated in DuPlan Corp v Deering Milliken, ${ }^{\mathrm{s}}$ where the court stated, "the nature of the interest [must] be identical, not similar, and [must] be legal, not solely commercial." ${ }^{\circ 6}$ The strictest reading of DuPlan's "legal, not solely commercial" language holds that insertion of commercial interests significantly limits application of common interest protection; that "calculated use of otherwise privileged materials for commercial purposes will waive the privilege." For example, one court concluded that the common interest doctrine did not apply when documents were shared "[i]n order to facilitate a joint business decision." ${ }^{, 88}$ A more liberal understanding of the common interest doctrine questions whether a common interest must be an identical interest. One court asserted: "The common interest privilege does not require a complete unity of interests among the participants. The privilege applies where the interests of the parties are not identical, and it applies even where the parties' interests are adverse in substantial respects."

Applying the DuPlan test, courts typically conclude that corporations engaged in commercial negotiations do not share an identical legal interest. For example, two corporations negotiating a joint venture could not invoke common interest protection for communica-

at all, the nature of the corporate attorney-client privilege arguably requires a liberal interpretation of "in anticipation of litigation."

85397 F Supp 1146 (D SC 1974).

86 Id at 1172. Applying this test, the DuPlan court found that sharing documents with an exclusive patent licensee waived the privilege. Id at 1175. Some courts refer to this test as the "Union Carbide test." See, for example, Rayman v American Charter Federal Savings \& Loan Association, 148 FRD 647, 654 (D Neb 1993), revd on other grounds, 75 F3d 349 (8th Cir 1996), referring to a case that cited DuPlan. See Union Carbide Corp v Dow Chemical Co, 619 F Supp 1036, 1047 (D Del 1985).

87 In Re John Doe Corp, 675 F2d 482, 489 n 5 (2d Cir 1982).

88 Bank Brussels Lambert v Credit Lyonnais (Suisse) SA, 160 FRD 437, 448 (SDNY 1995) (declining to find a common interest among several banks that jointly extended credit to a corporation, although the banks later engaged in litigation against the corporation, reasoning that "the common interest doctrine does not encompass a joint business strategy which happens to include ... a concern about litigation"). The DuPlan view disapproves of such a restrictive view of the common interest doctrine. "The fact that there may be an overlap of a commercial and a legal interest for a third party does not negate the effect of the legal interest in establishing a community of interest." DuPlan, 397 F Supp at 1172.

89 In re Mortgage \& Realty Trust, 212 BR 649, 653 (Bankr CD Cal) (applying common interest protection to communications between a bankruptcy debtor and a coalition of creditors, on the reasoning that, although the debtor and creditors were adverse as to certain issues, the parties were aligned in opposition to an outside creditor's claim). 
tions disclosed during negotiations. One court reasoned as follows: "That the overall profitability of the joint enterprise was a general consideration in which both parties' interests converged does not lessen the significance of their divergent interests." Similarly, sharing of privileged material during negotiations for the sale of goods has not warranted protection under the common interest doctrine."

B. Application of the Common Interest Doctrine in Substantial Transactions

Courts are split over whether common interest protection may apply to disclosures made during substantial transactions. One line of cases denies common interest protection because "parties at the negotiating table" have "insufficient" common interest to warrant exclusion of evidence. ${ }^{92}$ An opposing line of cases grants common interest protection, reasoning that "courts should not create procedural doctrine that restricts communication between buyers and sellers [and] erects barriers to business deals."

1. The Corning approach: declining to recognize common interest protection for disclosures made during substantial transactions.

One line of cases does not apply common interest protection to disclosures by corporations contemplating a substantial transaction, treating substantial transactions much like any other transaction. Animating this line of cases is the idea that common interest protection is inconsistent with the adversary positions of parties engaged in negotiations. In Corning, Inc v SRU Biosystems, $L L C{ }^{24}$ the court did not apply common interest protection to documents shared with a potential acquirer because disclosure occurred "not in an effort to formulate a joint defense but rather to persuade [the potential buyer] to invest."."95 Another court, declining protection where a corporation made disclosures to a potential buyer of one of its divisions, reasoned that "whatever the common interest shared by parties at the negotiating table, it is insufficient to warrant [protection]."

For courts following the Corning approach, the structure of a transaction carries weight in the common interest inquiry. In Cheeves

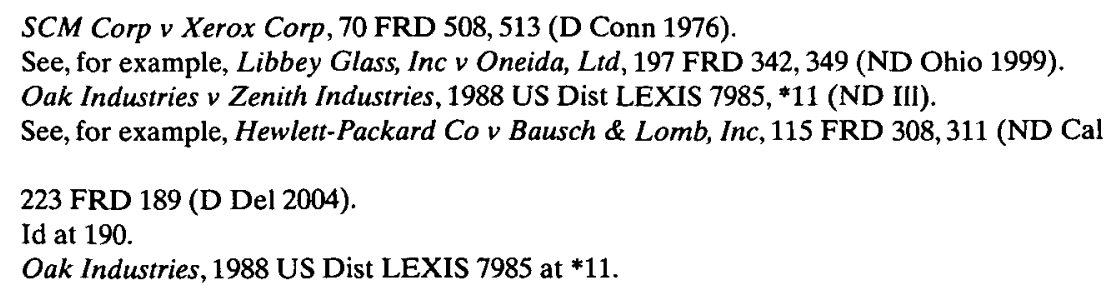


v Southern Clays, Inc, ${ }^{9}$ among other things, the court declined to protect communications shared in advance of a substantial asset sale, reasoning that the parties shared no common interest at the time of disclosure because "[i]f the corporation sells to another corporation its entire business operation and all its assets ... the two corporate entities remain distinct and intact. ${ }^{\prime 88}$ The Cheeves court suggested that the parties would have shared a common interest had the transaction been a merger instead of a substantial asset sale.

2. The Hewlett-Packard approach: recognizing common interest protection for disclosures made during substantial transactions.

Another line of cases, by contrast, allows common interest protection for communications shared between two corporations contemplating a substantial transaction. In Hewlett-Packard Co v Bausch $\& L o m b, I n c,{ }^{100}$ the court found that privilege was not waived when a corporation disclosed privileged communications during negotiations with a potential purchaser of one of its divisions. ${ }^{101}$ According to the court, common interest protection was warranted because both buyer and seller could face patent infringement litigation over a patent that would be transferred in the sale. ${ }^{102}$ The Hewlett-Packard court offered a policy argument on the proper level of court influence in private party negotiations, asserting that courts should only impose legal doctrines affecting private transactions when absolutely necessary:

Unless it serves some significant interest courts should not create procedural doctrine that restricts communications between buyers and sellers, erects barriers to business deals, and increases the risk that prospective buyers will not have access to important information that could play key roles in assessing the value of the business or product they are considering buying. ${ }^{103}$

The court further observed that granting common interest protection in such cases facilitates the operation of the adversary system, noting that "[1]egal doctrine that impedes frank communication between buyers and sellers also sets the stage for more lawsuits, as buyers are more likely to be unpleasantly surprised by what they receive."104

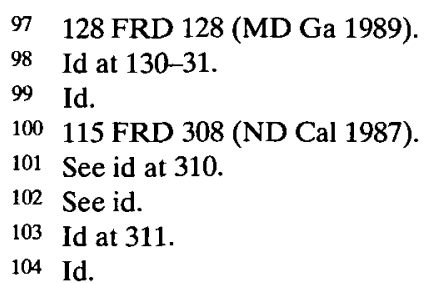


The Hewlett-Packard approach does not depend on a transaction's consummation. In Hewlett-Packard itself, the contemplated transaction was abandoned, but the court concluded that the parties reasonably anticipated joint litigation because "at the time the [document] was shared, there was a real possibility that [the buyer] would purchase [the division]." ${ }^{105}$ The Hewlett-Packard court's position on abandoned transactions appears to recognize that, at the time of disclosure, corporations can never be certain that a transaction will be consummated. ${ }^{106}$

Several courts have followed the Hewlett-Packard approach, recognizing a common interest between two corporations engaged in negotiations for a substantial transaction. ${ }^{107}$ For example, in Rayman $v$ American Charter Federal Savings \& Loan Association, ${ }^{108}$ the court concluded that the common interest doctrine protected disclosures made prior to a merger. The Rayman court acknowledged that the disclosures involved commercial interests, but did not see this fact as a bar to common interest protection. ${ }^{109}$ In Tenneco Packaging, Inc v S.C. Johnson \& Son, Inc, ${ }^{110}$ the court applied common interest protection to a patent opinion letter disclosed in an asset sale. ${ }^{11}$ The Tenneco court observed that disclosure occurred toward the end of negotiations: "Dow Brands disclosed the opinion to SCJ during the course of due diligence, when the asset purchase deal was largely locked up."112 Courts that follow Hewlett-Packard emphasize that allowing informa-

105 Id at 310.

106 For example, regulators might block a transaction under the antitrust laws.

107 Also, a few courts have applied common interest protection to work product shared during the course of merger negotiations. See, for example, United States $v$ Gulf Oil Corp, 760 F2d 292, 296 (Temp Emer Ct App 1985) (finding that sharing of documents in contemplation of a merger did not waive work product protection); Eagle Compressors, Inc v HEC Liquidating Corp, 206 FRD 474, 480 n 2 (ND Ill 2002) (same) (dicta). Common interest protection of work product differs somewhat from common interest protection of privileged communications because work product protection, unlike the attorney-client privilege, is waived only by disclosure to a litigation adversary.

108148 FRD 647 (D Neb 1993), revd on other grounds, 75 F3d 349 (8th Cir 1996).

109 See id at 653 ("The negotiations were aimed at completing a business merger.... Presumably, defendant supplied Metropolitan with information on this lawsuit so that Metropolitan would be more fully informed of the potential liability it would take on by merging with [defendant]."). The subject lawsuit was ongoing at the time of merger negotiations, and the Rayman court noted that " $\mathrm{t}]$ his case provides less room for speculation than did Hewlett-Packard: litigation here was not anticipated; it was a reality." Id at 654 . However, the court accepted the result in Hewlett-Packard. See id.

1101999 US Dist LEXIS 15433 (ND Ill).

111 Although the opinion gives little detail on the scope of the asset sale in question, it is clear that several patents were transferred in the sale. See id at *6-7. Given the substantiality of the asset sale, this Comment groups Tenneco with cases addressing change of control transactions, rather than with cases addressing everyday transactions.

112 Id at $* 8$. 
tion sharing during negotiations facilitates business transactions. ${ }^{113}$ For example, one court accepted a party's argument that "both companies [involved in a merger] shared a common legal interest in ensuring that the merger was appropriately evaluated and completed." ${ }^{14}$

3. Comparing the Corning approach and the Hewlett-Packard approach.

The contrast between the Corning approach and the HewlettPackard approach can be illustrated by an example. ${ }^{115}$ Consider two corporations $-A$ and $B$-contemplating a merger. In preparation for the merger, $A$ and $B$ allow each other access to business records and other documents. $A$ and $B$ enter into an agreement providing that, if the merger is abandoned, each corporation will return any documents belonging to the other corporation. $A$ and $B$ abandon the merger. Later, the United States government brings suit against $B$ and argues that $B$ must produce a privileged document it shared with $A$.

Under the Corning approach, common interest protection would not apply to the document $B$ shared with $A$, and the privilege would therefore be waived. A court following Corning might look to Cheeves, where the court suggested that a common interest is more likely in the context of a merger. ${ }^{116}$ However, given the abandonment of the merger, ${ }^{117}$ a court following the Corning approach would likely order production of the privileged document. By contrast, under the Hewlett-Packard approach, a court would find that $A$ and $B$ shared a common interest-especially if the court was satisfied that $A$ and $B$ took steps to preserve the confidentiality of the communication. ${ }^{118}$ The fact that the merger was abandoned is not dispositive.

As the foregoing example illustrates, the fact that courts do not consistently apply the common interest doctrine can lead to materially different results. The DuPlan test does not offer courts-or corporations - a sense of when the common interest doctrine might be suc-

113 See, for example, Britesmile, Inc v Discus Dental Inc, 2004 US Dist LEXIS 20023, *9 (ND Cal); Oxy Resources California LLC v Superior Court, 115 Cal App 4th 874, 9 Cal Rptr 3d 621, 642 (2004).

114 Cavallaro v United States, 153 F Supp 2d 52, 61 (D Mass 2001) (citing the HewlettPackard approach with approval, but declining to apply common interest doctrine in this case because only one of the parties invoking the doctrine was actually represented by counsel at the time of disclosure).

115 This example is based on the facts in Gulf Oil, $760 \mathrm{~F} 2 \mathrm{~d}$ at 293.

116 See Cheeves, 128 FRD at 130.

117 The transaction in Cheeves was consummated. See id at 129. It is uncertain how the Cheeves court would view an unconsummated merger.

118 See Hewlett-Packard, 115 FRD at 311 (emphasizing that the parties took steps to preserve the confidentiality of the disclosed documents). 
cessfully invoked. ${ }^{119}$ The test's uses of "legal" and "identical", at first glance appears clear-cut, but, in practice, results in a wide range of

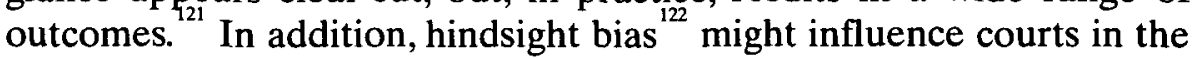
common interest inquiry. That is, if litigation emerges, and the parties formerly involved in business negotiations are aligned, a court may be more likely to find that the parties shared a common interest at the time of disclosure.

Given the split regarding disclosures during negotiations for substantial transactions, corporations contemplating an asset sale or merger cannot accurately assess the costs and benefits of disclosure. Normally, the law respecting corporations favors predictability, ${ }^{123}$ especially in transaction planning. The predictability of corporate law gives corporations a sense of when litigation can be expected, which allows corporations to better arrange their affairs. Evidentiary rules applicable in corporate litigation should be predictable for the same reason.

119 See Rayman, 148 FRD at 654 ("[T] [Te [DuPlan] test is not clear as to the meaning of 'common legal interest' and 'anticipate joint litigation."). The difficulty in applying the common interest doctrine is an inevitable product of its expansion. When the principle applied only to criminal co-defendants, see, for example, Continental Oil Co v United States, 330 F2d 347, 350 (9th Cir 1964), determining what constitutes a common interest was straightforward. When the common interest is applied in cases of "potential litigation," see, for example, Schachar v American Academy of Opthalmology, Inc, 106 FRD 187, 191 (ND Ill 1985), the inquiry is more difficult.

120 DuPlan, 397 F Supp at 1172.

121 See Part III.B.

122 For a general discussion of hindsight bias, see Norman G. Poythress, Richard Wiener, and Joseph E. Schumacher, Reframing the Medical Malpractice Tort Reform Debate: Social Science Research Implications for Non-Economic Reforms, 16 L \& Psych Rev 65, 99 (1992) ("What is difficult for the person with a hindsight perspective or outcome knowledge to do, however, is to accurately describe or portray the probabilities and judgments that existed at the time that the critical decisions were made."). See also Ulrich Hoffrage, Ralph Hertwig, and Gerd Gigerenzer, Hindsight Bias: A By-Product of Knowledge Updating?, 26 J Exp Psych: Learning, Memory \& Cognition 566, 579 (2000).

123 See, for example, Speiser v Baker, 525 A2d 1001, 1008 (Del 1987) (emphasizing that Delaware courts construing statutes governing corporations must strive to promote predictability because "most transactions ... are carefully planned and result from a thoughtful and highly rational process"). There are examples of uncertainty in corporate law, such as the uncertain application of the veil piercing doctrine. See Frank H. Easterbrook and Daniel R. Fischel, Limited Liability and the Corporation, 52 U Chi L Rev 89, 89 (1985) ("Courts occasionally allow creditors to 'pierce the corporate veil' ... . 'Piercing' seems to happen freakishly. Like lightning, it is rare, severe, and unprincipled."). 


\section{TOWARD A PREDICTABLE APPROACH TO THE COMMON INTEREST DOCTRINE FOR DISCLOSURES DURING NEGOTIATIONS FOR SUBSTANTIAL TRANSACTIONS}

\section{A. Pros and Cons of a Regime with No Common Interest Protection for Disclosures Made during the Course of Business Transactions}

The most predictable regime of common interest protection is one in which common interest protection is not extended to any disclosures between parties engaged in negotiations. ${ }^{124}$ That is, corporations would not face uncertainty if courts categorically denied common interest protection when communications are shared "in order to facilitate a [] business decision."

1. There are strong arguments in favor of a categorical rule.

Arguably, a common interest never exists between parties engaged in negotiations for a transaction: two parties on opposite sides of a transaction are fundamentally adverse. ${ }^{126}$ And a blanket rule of waiver would reduce the exclusion of evidence on privilege grounds. ${ }^{127}$ Lastly, a categorical rule would simplify application of the common interest doctrine for courts, thereby saving judicial resources. ${ }^{128}$

However, there are compelling reasons to protect at least some sharing of privileged documents between corporations contemplating a change-of-control transaction. A categorical rule of waiver implicates the policy concern, aired in Hewlett-Packard, that courts should avoid adopting evidentiary rules that interfere with private transac-

124 Another highly predictable regime is one in which parties are allowed to determine when a common interest exists between them. One commentator suggests such a regime, and argues that courts should enforce common interest agreements between parties. See Fischer, 16 Rev Litig at 643-44 (cited in note 74) (“[T]he parties' decision should be respected, absent additional, separate factors suggesting that the privilege should be deemed lost."). However, in such a regime, parties who did not actually share a common interest-in the doctrinal sense-could easily mimic those who do share a common interest. Assigning the common interest determination to the court, not the parties, ensures that common interest protection is applied only when justified, minimizing the degree of evidence shielded from scrutiny.

125 Bank Brussels Lambert v Credit Lyonnais (Suisse) SA, 160 FRD 437, 448 (SDNY 1995).

126 See, for example, Oak Industries v Zenith Industries, 1988 US Dist LEXIS 7985, *11 (ND III) (suggesting that "parties at the negotiating table" share little, if any, common interest).

127 See United States $v$ Nixon, 418 US 683, 710 (1974) (emphasizing that privilege protection is "in derogation of the search for truth").

128 Privilege determinations typically involve in camera review of documents for which privilege is claimed. See, for example, Rayman, 148 FRD at 655 (noting that defendant, objecting to plaintiff's document requests on grounds of "privilege, overbreadth and relevance," presented ninety-five documents for in camera review). 
tions. ${ }^{129}$ And a categorical rule conflicts with the Supreme Court's formulation of the corporate attorney-client privilege.

2. But the Supreme Court's articulation of the corporate attorney-client privilege forecloses a regime where the common interest doctrine never applies to disclosures during negotiations.

The corporate attorney-client privilege, in addition to protecting the attorney-client relationship, also encourages corporations to seek the legal advice necessary to conform corporate conduct to the law. ${ }^{130}$ The Supreme Court's recognition of this additional rationale for the attorney-client privilege indicates that corporations' frequent contact with government regulation is an important consideration when establishing the scope of protection. ${ }^{131}$

The purpose of the common interest doctrine is to allow parties with a common interest to share information when litigation is imminent or anticipated. Given that, as the Upjohn Court emphasizes, corporations face significant government regulation, ${ }^{132}$ corporations are likely to benefit from the common interest doctrine more frequently than individual litigants. The additional regulatory burdens on corporations are also relevant to the question of how courts should apply the common interest doctrine to corporate disclosures. A restrictive approach to the common interest doctrine ${ }^{133}$ gives too little weight to Upjohn's additional justification for recognizing the attorney-client privilege in the corporate setting.

Moreover, courts should avoid overly rigid application of the common interest doctrine to disclosures during corporate transactions. First, because corporations must frequently consult counsel, corporations are likely to generate and maintain a large volume of privileged communications. Given the sheer volume of privileged communications, negotiations in the corporate setting will lead to sharing of privileged communications more frequently than will negotiations between individuals. ${ }^{134}$ Second, much of the everyday business conduct of corpora-

129 See Hewlett-Packard, 115 FRD at 311.

130 See Upjohn, 449 US at 392.

131 See id.

132 See id. Heavy government regulation of corporations increases the likelihood of government litigation against corporations, but also renders corporations more vulnerable to suit by private parties.

133 Compare id (criticizing the "narrow scope" of the control group test adopted by the court of appeals).

134 Although confidential material is frequently shared in transactions between individuals, the confidential material will likely not enjoy the protection of the attorney-client privilege. For example, a potential buyer of real estate might share confidential financial statements with the seller. 
tions implicates legal issues. ${ }^{135}$ The DuPlan court stressed that a common interest must be "legal, not solely commercial." ${ }^{136}$ If everyday business conduct is inextricably tied with legal matters, negotiations between corporations will inevitably touch on legal questions, and a shared interest between two corporations will often bear legal implications.

Both the corporate attorney-client privilege and the common interest doctrine have emerged concurrently with the rise of the administrative state-which has augmented corporations' contact with government regulation ${ }^{137}$-and increasingly complex litigation. It is important that courts give full consideration to the Supreme Court's rationale for the corporate attorney-client privilege when establishing the limits of the common interest doctrine.

\section{B. Under What Circumstances Is Common Interest Protection Most Justified?}

Instead of imposing a categorical rule of waiver, a better approach is to determine under what circumstances two corporations contemplating a transaction are most likely to share a common interest and to determine under what circumstances the case for waiver is weakest. When the common interest is strong, and when the justification for implied waiver is shaky, there is a powerful case for application of common interest protection. If courts recognize under which circumstances application of the common interest doctrine is most justified, they can presume a common interest when these circumstances are met, rendering application of the doctrine simpler and less costly. If corporations know which factors will give rise to a presumption of a common interest, they will be able to plan transactions with a better understanding of waiver risks.

The likelihood of common interest is higher when corporations contemplate a substantial transaction-especially a transaction that would involve a shift in management. However, protection for all disclosures during the course of substantial transactions would result in overly broad exclusion of otherwise admissible evidence. This Comment proposes narrowing the inquiry by focusing on two questions:

135 In applying the attorney-client privilege to communications with lower-level employees, the Supreme Court has recognized the degree to which legal issues are implicated in everyday business. See Upjohn, 449 US at 394 (noting that the communications at issue "concerned matters within the scope of the employees' corporate duties").

136397 F Supp at $\mathbf{1 1 7 2 .}$

137 See FTC $v$ Ruberoid Co, 343 US 470, 487 (1952) (Jackson dissenting) (noting the administrative state's ascendance during the last century and commenting on the broad reach of administrative action). See also text accompanying notes $75-78$. 
First, what objective indicators of a common interest existed in the parties' relationship when communications were disclosed? Second, at what point during negotiations were communications disclosed?

\section{Succession to liabilities as an objective indicator of common interest.}

When the contemplated transaction will lead to a transfer of liabilities from one party to the other, this fact is a strong indicator of common interest. The parties may reasonably anticipate that joint efforts would be necessary in future litigation surrounding transferred liability. Although a seller transfers its liability to a buyer, under certain circumstances the seller will not be immune from suit.

Courts could assess whether liability will be transferred in a substantial transaction by looking to the terms of the deal between the parties. For example, if the parties to a substantial asset sale agree that the buyer would assume any liabilities stemming from the seller's employment practices, this fact suggests that the parties share a common interest regarding employment liabilities. However, this approach is flawed because the terms of the deal will likely fluctuate throughout negotiation; parties may plan to transfer certain liabilities at the time of disclosure, but later make changes to their deal. ${ }^{139}$ Because dickered-for transfers of liabilities are not set in stone before a transaction is consummated, courts should look to an objective indicator that liability will transfer.

Automatic succession to liabilities is one such objective indicator. Whether a transaction will result in succession to liabilities can be determined by looking to the structure of a deal. While parties may repeatedly renegotiate liability transfer terms, there is less risk that the structure of a deal will fluctuate. Moreover, courts may look to existing rules for determining whether a transaction will result in successor liability. ${ }^{100}$ It is true that successor liability rules are not always easy to apply - the Seventh Circuit described federal successor liability law as "dreadfully tangled." ${ }^{141}$ However, case law on successor liability may

138 For example, liability for contamination clean-up under CERCLA may arise against both "the owner and operator of ... a facility" or "any person who at the time of disposal of any hazardous substance owned or operated any facility at which hazardous substances were disposed of." 42 USC $\S 9607(2000)$. That is, both the current owner and a past owner of a facility may face liability.

139 See, for example, Katz, Due Diligence in Acquisition Transactions at 261 (cited in note 6) (noting that due diligence informs buyers as to the appropriate price and terms to negotiate, and emphasizing that the transaction's price should reflect any liabilities that are transferred).

140 See Part I.B. Some observers would contest that successor liability consists of clear rules.

141 EEOC $v$ Vucitech, 842 F2d 936, 944 (7th Cir 1988). The Seventh Circuit characterizes successor liability as "tangled" because ii : $\cdot$ quires balancing two competing interests: (1) the 
serve as a guide, whereas, in practice, the common interest doctrine is an ad hoc inquiry. Application of successor liability rules would therefore simplify the question of whether a common interest existed between parties at the time of disclosure.

Another reason courts should look to succession law is that successorship is tied to whether the attorney-client privilege transfers in a transaction. ${ }^{142}$ Privileged communications disclosed during negotiations are probably very valuable to the potential acquirer because they address litigation risks. Post-acquisition, the acquirer will wish to maintain privilege protection for such communications. By contrast, privileged communications not disclosed during negotiations, and which do not address litigation risks, are likely less valuable. It would be a strange result to extend protection to less-valuable privileged communications that transfer post-transaction while imposing implied waiver on more valuable communications that were disclosed during the transaction.

2. The due diligence phase of a transaction as a time frame during which corporations are more likely to share a common interest.

During the due diligence phase, the norms of buyer-seller disclosure change. Historically, under caveat emptor, a seller of real property has no duty to disclose defects. ${ }^{143}$ Contemporary doctrine imposes a duty of disclosure when a seller invests little effort in acquiring relevant information, but the nondisclosure rule survives when a seller invests significant resources or effort in acquiring that information. ${ }^{1.4}$ In due diligence, however, seller corporations regularly disclose "defects" that were very expensive to discover. For example, a corporation may incur significant legal costs in determining whether it might face CERCLA liability in the future. Nevertheless, a potential buyer would likely expect that such knowledge be disclosed, despite the expense incurred. ${ }^{145}$ In summary, the norm of disclosure during due dili-

policy of compensating for corporations' externalization of costs; and (2) the importance of fluid capital markets where assets can be freely exchanged. Id. Although this balancing inquiry will often pose a challenge for courts, using successor liability in common interest determinations offers courts a clear sense of what interests must be weighed.

142 See text accompanying notes 35-38.

143 See Anthony T. Kronman, Mistake, Disclosure, Information, and the Law of Contracts, 7 J Legal Stud 1, 22-24 (1978).

144 See id at 16. For example, when a seller knows that his house is infested with termites, he has a duty to disclose this "latent defect" to a potential buyer. See id at 24 , citing Obde v Schlemeyer, 56 Wash $2 \mathrm{~d} 449,353 \mathrm{P} 2 \mathrm{~d} 672,675$ (1960) (imposing on a seller the duty to disclose to potential buyers the existence of a termite infestation).

145 The buyer would expect that the seller's actual knowledge of CERCLA liability would be shared given the unpredictable, potentially enormous scope of liability. See Fort, Patrick, and Flowers, Due Diligence for Environmental Issues in Transactions at $\$ 1.1$ (cited in note 6) (em- 
gence is more demanding than the legal requirements generally imposed on sellers. This robust disclosure norm highlights that due diligence disclosures are in many ways distinguishable from disclosures occurring earlier during negotiations.

Specifically, due diligence disclosures differ from earlier disclosures in two relevant ways. First, the parties are less adverse at the due diligence phase. Second, the arguments for implied waiver are weaker when disclosure occurs during the due diligence phase of a transaction. ${ }^{1.6}$

a) The fact that negotiations have reached the due diligence phase indicates a lower risk that adversity overwhelms any common interest between the parties. Because due diligence is an expensive undertaking for both buyer and seller, the parties' decision to proceed at this stage indicates increased likelihood that the transaction will be consummated.

Before the consummation of a transaction, the parties' adversary positions overwhelm any shared common interest. Indeed, courts cite adversity between parties as a barrier to common interest protection; for example, one court states: "[W] hatever the common interest shared by parties at the negotiating table, it is insufficient to warrant [protection]." ${ }^{477}$ Of course, this concern disappears (or at least becomes functionally nonexistent) with consummation of a transaction; if the parties anticipate litigation, a post-transaction disclosure would of course fall under common interest protection. And, arguably, as a transaction moves closer to consummation, such concerns lessen.

Also, due diligence review involves extensive cooperation between parties. Although each party still pursues an individual agenda during due diligence-the buyer, in particular, seeks to assess the transaction's risk - the parties share an interest in completing the process quickly and thoroughly.

b) The justifications for implied waiver apply less squarely in the case of due diligence disclosures. This is the case because a strong disclosure norm - which is really the product of several legal rulessignificantly influences parties' conduct during the due diligence phase of a transaction. Several legal rules shape due diligence disclosure practice. To avoid process duty of care liability, ${ }^{149}$ a sophisticated buyer corporation will always request production of any documents

\footnotetext{
phasizing that it is essential for buyers to engage in environmental due diligence because environmental liabilities impose the risk of "being blind-sided by catastrophic losses").

146 See Tenneco, 1999 US Dist LEXIS 15433 at $* 8$ (noting that the fact that disclosure occurred during due diligence weighed towards application of common interest protection).

147 Oak Industries, 1988 US Dist LEXIS 7985 at *11.

148 See Tenneco, 1999 US Dist LEXIS 15433 at *8 (suggesting that disclosures later in the course of negotiations do not implicate the same concerns that parties are adverse).

149 See Smith v Van Gorkom, 488 A2d 858, 872 (Del 1985) (imposing liability on directors who failed to inform themselves adequately before agreeing to a merger).
} 
that go to any legal issues. In response to the buyer's request, a seller will predictably disclose. ${ }^{1.0}$ If the seller possesses documents that fall within the descriptions of documents requested by the buyer, withholding the documents may constitute misrepresentation. ${ }^{\text {ist }}$ In theory, the seller could indicate that it possesses relevant documents, but refuse to disclose the documents, thereby trading off privilege protection for a lower price. ${ }^{152}$ In practice, however, the seller's refusal to disclose-contrary to the prevailing norm - would send a strong signal that the transaction carries significant risks. The buyer would likely interpret the seller's refusal as evidence that the deal is a risky transaction. In summary, a legal rule-process duty of care-shapes the norm, and the norm, in concert with the law of misrepresentation, strongly influences the seller's disclosure.

Given the element of influence in due diligence, the rationales for implied waiver of privilege doctrine offer weaker justification for construing due diligence disclosures as waivers. ${ }^{153}$ One justification for the doctrine of implied waiver is that disclosure is evidence of the privilege-holder's intent to waive. ${ }^{1.44}$ But because of the strong due diligence norm, the intent justification for the implied waiver rule is problematic here. Considerations other than intent to waive privilege motivate sellers who disclose during due diligence.

Another justification for implied waiver is that disclosure is inconsistent with the purpose of the privilege. However, voluntariness of conduct is key to this justification, too. For example, one court expressed this justification as follows: "Any voluntary disclosure by the holder of [the attorney-client] privilege is inconsistent with the confidential relationship and thus waives the privilege."155

The fairness rationale for implied waiver, which holds that a finding of waiver is justified when a party's partial disclosure creates confusion or "truth-garbling," sures. However, waiver for fairness reasons involves a case-by-case

150 In some cases, the seller has a duty to disclose certain matters, independent of the buyer's request for disclosure. The Hewlett-Packard court, for example, suggests that seller corporations have a duty to disclose that a division offered for sale is likely to face litigation. See 115 FRD at 308. However, the court notes that there was no duty (outside of due diligence) to disclose a privileged patent opinion letter that would shed light on the anticipated litigation. See id at 308-09.

151 See FDIC v W.R. Grace \& Co, 877 F2d 614, 619 (7th Cir 1989) ("An omission can of course be actionable as a fraud.").

152 Compare notes 14-17 (discussing how due diligence information sharing affects the price and terms of a substantial transaction).

153 See text accompanying notes 65-69.

154 See Suburban Sew 'N Sweep, Inc v Swiss-Bernina, Inc, 91 FRD 254, 260 \& n 4 (ND Ill 1981).

155 United States $v$ AT\& T, 642 F2d 1285, 1299 (DC Cir 1980).

156 See Marcus, 84 Mich L Rev at 1627 (cited in note 65). 
inquiry into the impact of disclosure. ${ }^{157}$ Fairness considerations do not undermine the conclusion that generally, the case for implied waiver is weak respecting due diligence disclosures.

The element of influence in due diligence is not, by itself, sufficient justification for an exception to the implied waiver doctrine. Courts rejecting the selective waiver exception to implied waiver doctrine emphasize that protection is not supported simply because an entity would face unpleasant consequences if it did not disclose. For example, one court noted that the fact that an entity found itself "between ... a rock and a hard place ... [was] insufficient justification for carving a substantial exception to the waiver doctrine." the due diligence disclosure norm influences disclosure cannot, by itself, protect privileged communications. But, in the context of the common interest doctrine, the disclosure norm differentiates the due diligence phase from other phases of the transaction.

c) Courts applying the common interest doctrine should treat disclosures during due diligence differently than disclosures during initial negotiations. There is a lower risk that adversity overwhelms the parties' common interest when disclosure occurs during due diligence, rather than during initial negotiations. Also, the case for implied waiver is weaker for due diligence disclosures, indicating that courts should tread carefully in reading disclosure to constitute waiver in that context.

Furthermore, drawing the line at the due diligence phase simplifies the inquiry for courts. Parties to a contemplated transaction take distinct actions to initiate due diligence; ${ }^{159}$ the starting point of this phase could easily be identified. Also, by the due diligence phase, the parties will probably have decided how the transaction will be structured; at this point, the parties are less likely to restructure an asset sale as a merger. ${ }^{160}$ As a result, the relevant successor liability rule is unlikely to change.

157 See id at 1649 (describing the fairness inquiry as a "multi-factor analysis to determine whether it would be 'fair' to allow privilege holder to continue to assert the privilege").

158 In re Steinhardt Partners, LP, 9 F3d 230, 236 (2d Cir 1993).

159 See Committee on Negotiated Acquisitions, The M\&A Process at 196 (cited in note 11) (describing, among other things, the establishment of a data room and the buyer's preparation of due diligence requests).

160 Indeed, the transaction's structure will dictate how the due diligence review proceeds. See Fahmi, IP Due Diligence at 857-58 (cited in note 17) ("Knowing what the contemplated form of transaction is is [sic] an absolute necessity towards development of the due diligence plan. Without an understanding [sic] the deal structure, the investigating attorney will not be properly prepared for the investigating activities to come."). 


\section{A Presumption of Common Interest}

1. Articulating a presumption.

A regime where common interest protection does not apply to corporations negotiating a transaction leads to predictability; however, such a rigid rule denies protection in many cases where corporations legitimately share a common interest. The Corning approach is therefore undesirable. By contrast, a purely ad hoc inquiry renders substantial transaction planning very difficult for corporations. A better approach is to apply a presumption under narrow circumstances where a common interest is likely to exist. This Comment proposes that a presumption apply where two factors are met: where the contemplated transaction would result in automatic succession to liabilities ${ }^{161}$ (that is, where the transaction is a merger or a substantial asset sale where there is "continuity between the predecessor's and successor's businesses and the latter's notice of the former's acts" ${ }^{162}$ ) and where the privileged communications were disclosed during due diligence review for that transaction. ${ }^{163}$ There are two ways a court could structure this presumption. First, courts might presume that there is a common interest under these circumstances. Alternatively, courts might presume that there is no common interest unless the contemplated transaction would lead to successor liability, and the disclosure occurred during due diligence.

The former, broader approach gives corporations more flexibility in planning transactions. The Hewlett-Packard approach endorses such flexibility, asserting that courts should not erect barriers to business communications. ${ }^{164}$ But the latter, more narrow approach has the advantage of preventing overly broad application of the common interest doctrine, which aligns with the Supreme Court's assertion that "exceptions to the demand for every man's evidence are not lightly created nor expansively construed." 165 The narrow presumption is preferable because it limits the scope of common interest protection for dis-

161 As discussed above, some exceptions to the no-successor liability default rule for asset sales exist in order to prevent fraud to creditors. Because courts will likely prefer not to reward fraudulent conduct with greater privilege protection, the presumption could be limited to successor liability exceptions - such as product line successor liability - that are not predicated on fraud.

162 Vucitech, 842 F2d at 944.

163 Tying successor liability and due diligence as an indicator of common interest would help ameliorate a problem inherent to allowing claims against successors. "[The] fluid market in corporate assets [ ] is impeded if purchasers acquire along with the assets legal liabilities of unknown, sometimes unknowable, dimensions." Id. Common interest protection allows successors to uncover risks of liabilities during due diligence review.

164 See Hewlett-Packard, 115 FRD at 311.

165 Nixon, 418 US at 710. 
closures during the course of substantial transaction negotiations, while still addressing the Hewlett-Packard court's concern that courts should avoid "imped[ing] frank communication between buyers and sellers."

This Comment therefore recommends that, for disclosures made during the course of a substantial transaction, courts presume that common interest protection applies only when disclosure was made during due diligence and the transaction would have resulted in succession of liabilities. This presumption should be rebuttable; corporations could still argue common interest protection for a disclosure outside of due diligence or during the course of transaction that would not lead to succession.

\section{Objections and responses.}

One possible objection to application of a presumption is that it constitutes a novel privilege. Courts' discretion to invent privileges is very limited. ${ }^{167}$ However, the proposed presumption is not properly characterized as a novel privilege; instead, it is a means to standardize interpretation of the common interest doctrine, a judicially-created concept. And the common interest doctrine's similarity to workproduct protection suggests that courts should enjoy more flexibility in fashioning a new approach in this area. ${ }^{168}$

Second, proponents of the Corning approach may object that application of a presumption will lead to overbroad common interest protection; that is, a presumption will result in exclusion of evidence where disclosure should be compelled. To some extent, this is undoubtedly true: in some cases, corporations contemplating a substantial transaction will not share a common interest even when disclosure falls into the succession and due diligence categories.

Courts can reduce the danger of overbroad exclusion to some extent through rigorous attention to the other prongs required for common interest protection. Even with adoption of a presumption, the common interest doctrine applies only under narrow circumstances. A finding that a common interest existed at the time of disclosure is only one component necessary for application of common interest protection. The court will also consider whether "the communication was designed to further [the anticipated joint litigation],"

166 Hewlett-Packard,115 FRD at 311.

167 See Trammel $v$ United States, 445 US 40, 50 (1980) (asserting that a novel privilege may be established only when "public good transcend[s]" litigants' right to uncover all relevant evidence).

168 See text accompanying notes 79-81.

169 In re Mortgage and Realty Trust, 212 BR 649, 653 (Bankr CD Cal 1997) (citations omitted). 
privilege has ... been waived, ${ }^{110}$ and whether the parties took steps to preserve the confidentiality of the privilege. ${ }^{171}$

Also, the potential cost of overbroad exclusion is somewhat reduced because of the negative effects inherent in permitting discovery of an adverse party's attorney product. Often, the document sought to be discovered-for example, a patent opinion letter-will be valuable to a party simply because an opinion expressed within the document undermines the adverse party's current position. The Hewlett-Packard court derides this practice, observing that "[p]reoccupation with efforts to paint opposing counsel into some semantic corner or to take advantage of his choice of terms leads to costly, unproductive, and unseemly disputes." 172 The demand for "every man's evidence" is less compelling when fueled by desire to exploit an attorney's choice of words.

A third objection to a presumption is that distinguishing between due diligence disclosures and disclosures during initial negotiations will push corporations to disclose during due diligence. If the presumption influences corporations to disclose during due diligence, then the fact that a disclosure occurred during due diligence is a weaker predictor of common interest. This result would likely follow if courts widely adopted the recommended presumption. However, courts will still inquire whether the disclosure actually furthered the presumed common interest, which will limit the effect of a shift towards due diligence disclosures.

\section{CONCLUSION}

The details of litigation can never fully be anticipated, and litigants will inevitably continue to find that prior conduct during business negotiations impliedly waived the attorney-client privilege. However, by presuming common interest protection under certain circumstances, courts can provide greater predictability to corporations engaged in negotiations for substantial transactions. This Comment therefore recommends that courts presume corporations shared a common interest at the time of disclosure only if disclosure occurred during due diligence review and if the contemplated transaction would have resulted in succession to the seller's liabilities. Even if courts decline to adopt a presumption, corporations engaged in negotiations should consider whether their relationship bears objective indicators of a common interest before disclosing privileged communications to further a transaction.

170 Id.

171 Libbey Glass, Inc v Oneida Ltd, 197 FRD 342, 348 (ND Ohio 1999).

172 Hewlett-Packard, 115 FRD at 311-12. 